\title{
White and Black Rhinoceros in Rhodesia
}

\author{
By H. H. Roth
}

This account of the past and present status of both species of rhinoceros in Rhodesia was presented by the author, in his capacity as Assistant Director (Research) of National Parks and Wildlife Management in Rhodesia, to the Survival Service Commission of IUCN in 1965, and since brought up to date. Dr. Roth, who is now Wildlife Officer of the UN Food and Agriculture Organisation (FAO), describes how both species have been eliminated from large areas not only by human settlement but also by tsetse control operations, and shows the importance of modern techniques of translocation, both for saving threatened populations and reducing local over-populations.

GEVERAL authors have published accounts of the historical occurrence

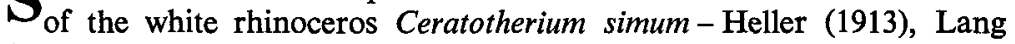
(1923), Harper (1945) - and Zukowsky (1964) has done the same for the black rhinoceros Diceros bicornis, but records of the local distribution of the two species within their ranges are very scanty. Player and Feely (1960) and Bigalke (1963) therefore reviewed the literature and hunters' diaries to show in more detail the past recession of the white rhinoceros from South Africa, and the present study endeavours to do the same for both black and white rhinoceros in Rhodesia south of the Zambesi. In addition to a study of the literature, old residents were interviewed and invited through newspaper advertisements to submit personal experiences of rhinoceros prior to 1935 .

The early occurrence of both African species over large parts of Rhodesia south of the Zambesi is well supported by numerous bushman rock paintings, such as that illustrated. Whereas the black rhinoceros at one time inhabited the whole of the densely covered Zambesi valley, and still extends north of it, no evidence was found in the literature that the southern white rhinoceros, which prefers open bushveld, has ever in fact occurred in the low, hot valley below the Zambesi escarpment. (See the map, page 226). The exact north-eastern and eastern limits of the white rhinoceros in historical times also remain uncertain. Nicolls and Eglington (1892), in a note on the approaching extinction of the species, mentioned "north-east Mashonaland" and the "Sabi River" as localities, but no original hunters' records were found for the Sabi valley; however, Orford (1965; pers. comm.) has reported that old tribal Africans in the Chipinga District distinguish in their language between two different rhinoceros species which they still seem to remember.

Player and Feely (1960) state that the white rhinoceros never resided on the high plateaus of the Transvaal and the Orange Free State, but in Rhodesia there is abundant evidence that the species inhabited and perhaps preferred the watershed plateau between the Zambesi and Sabi drainages, which at altitudes of $3,500-4,900$ feet comprises large tracts of 
open grassland. This watershed was the regular route of the early travellers from Transvaal to Mashonaland via Bulawayo, King Lobengula's residence, and the white rhinoceros must have been quite common along this route until 1874-80. In 1878 Selous (1881) still saw up to five animals per day between the Sebakwe and Hunyani Rivers. Only after 1880 did the numbers decrease rapidly due to the increase of commercial hunting for horn, which in turn, according to Selous, was mainly the result of diminishing profits from ivory hunting. The traders coming up from the south hired Matabele, and some of them are reported to have used several hundred native hunters at a time. Selous estimated that at least 1,000 rhinoceros were killed in Matabeleland during the five years prior to 1886; after that year only a few survived south of the Umfuli River.

Fewer travel records exist for the Midlands, the country between Umvuma, Fort Victoria and the southern Lowveld, and in none of the reports studied is there any mention of either species of rhinoceros. This, however, should not be interpreted as evidence for their absence. There was certainly suitable habitat for both species in this part of Rhodesia, including the Limpopo Lowveld, and the lack of records is probably mainly due to the more restricted hunting in those areas in early times, although the white rhinoceros may have been less numerous there.

The abundance of the white rhinoceros on the Dett Vlei is well documented, as the map shows, and prior to 1880 they were probably distributed over large parts of the present Wankie National Park. It seems unlikely, however, that the range of this rhinoceros species extended much north of the Gwaai-Shangani River Valley into the lower Zambesi drainage. This area, the Sebungwe District, consists of undulating brachystegia or mopani woodland and, because of its remoteness from the favoured hunting grounds and particularly its heavy tsetse fly infestation, pockets of rhinoceros would have survived the destruction of the species in Matabeleland and been recorded by some hunters later on, as has happened in other remote areas.

In north-western Mashonaland, the white rhinoceros certainly existed until 1893 (Coryndon 1894), but a few stragglers might have survived much longer in this and other peripheral areas. Whitby (1964 pers. comm.) claimed to have shot a white rhinoceros near Gota Gota hills just below the Zambesi escarpment as late as 1912. The skull of this animal was sent to Messrs Ward in London, but due to the loss of all their relevant records in World War II, it was impossible to verify this report. Bulpin (1964), in his biography of a locally well-known ivory hunter, described in detail the occurrence of white rhinoceros on the Tshingwezi river just north-west of the present Gona-e-zhou game reserve, between Lundi and Nuanetsi Rivers, and dates this 1913. It does in fact, appear that white rhinoceros survived longest in this south-eastern corner of Rhodesia, which was virtually unknown to most of the early naturalists. Apart from some doubtful reports, Kemp (1964 pers. comm.), an experienced hunter who should have been able to distinguish the two species, in 1929 observed at a short distance a bull and cow white rhinoceros at a pan between Chipinda Pools and the Sabi River, not far from the Mozambique border. 


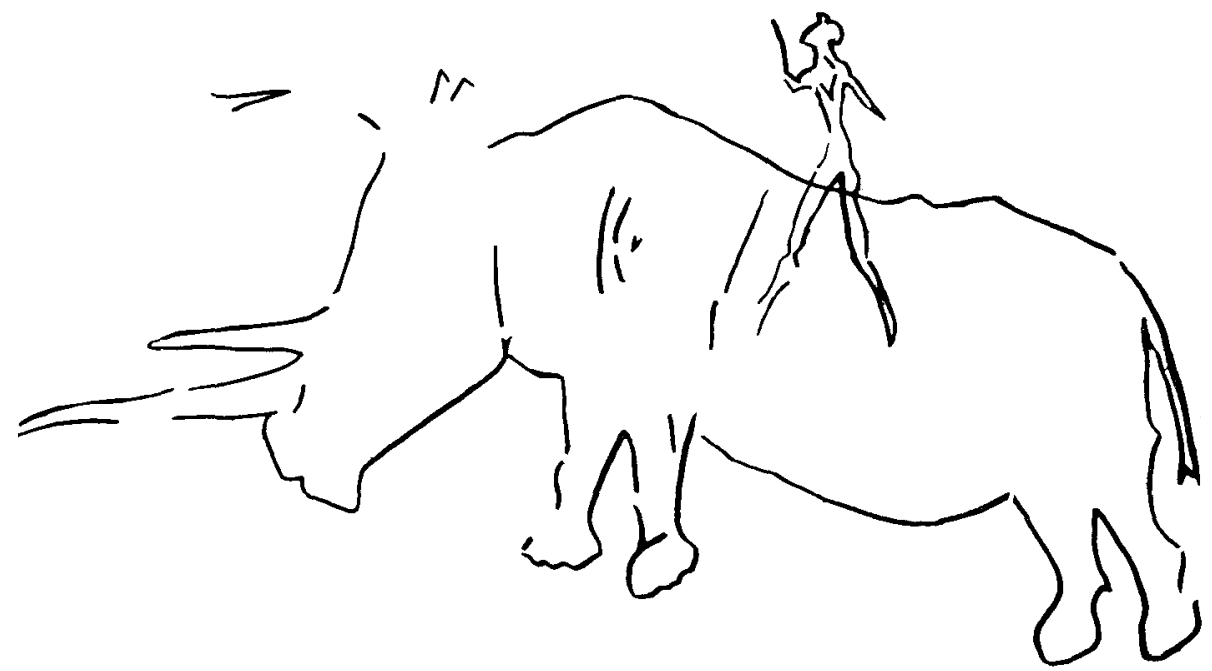

The black rhinoceros stood up much better to the severe hunting pressure of early white settlement and has survived in considerable numbers, not only because of its different habits and temperament which made hunting more difficult, but also because of its presumably much wider original distribution. As a predominantly browsing animal it likes to live in dense bush, which is found almost everywhere, but particularly in the lower areas. In contrast to the white rhinoceros it has always been abundant in the Zambesi valley and its tributary system. However, black rhinoceros were also apparently as common as the white on the high plateau between Salisbury and Bulawayo, mainly along river courses with dense bush vegetation. Selous (1908) describes how he was almost killed by a charging rhinoceros only about 30 miles south-west of the present Salisbury, near his favourite hunting base camp on the Hunyani River. In these early settled areas the bulk of the species seems not to have survived much longer than the white rhinoceros, although, a few were still shot in the Gatooma area up to 1940 during tsetse control operations. Outside Queque and in the Lower Gwelo area individual animals were seen quite frequently up to 1935 , and Scott (1965 pers. comm.) gave a good record of a resident rhinoceros crossing the road to Gwelo in 1938. One family group is known still on a ranch $\mathbf{3 0}$ miles south-west of Queque.

The areas from which rhinoceros were eliminated, together with other game animals, from 1924 onwards as a means of tsetse fly control are shown on the map, and Table 1 lists the officially recorded kills for each district. Bearing in mind that these operations were only part of general agricultural expansion, accompanied by increasing human disturbance, illegal hunting and habitat change, it becomes clear how the distribution of the black rhinoceros in northern Mashonaland, where they had remained widespread and abundant until the twenties, was rapidly reduced from 1924 onwards. Nicolle (1965; pers. comm.) for example, recalls that between 1932 and 1934 no fewer than 66 rhinos were shot in one restricted area north of Doma. 


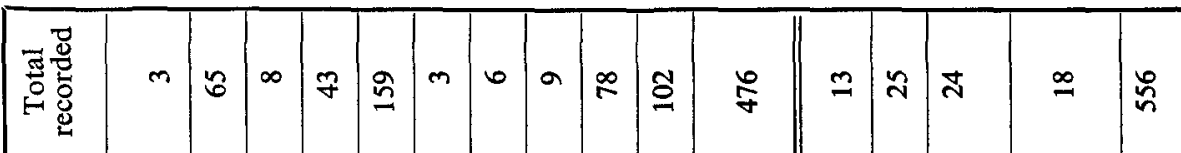

㟧号 
迅焉

온형

5

ن흄

\&

要.=

>ic

홍

总是

牙语

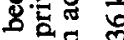

कo

氝.

.

范要

on

․․․

政

플

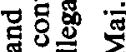

त

这要

至

氮总 总

空

空讨

동

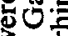

35

둥ㅇ

范

E는

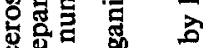

8

ㅇ.

은

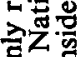

ㄷํ잉

施客念

온?

녕 क्षे क्ष

专

象题

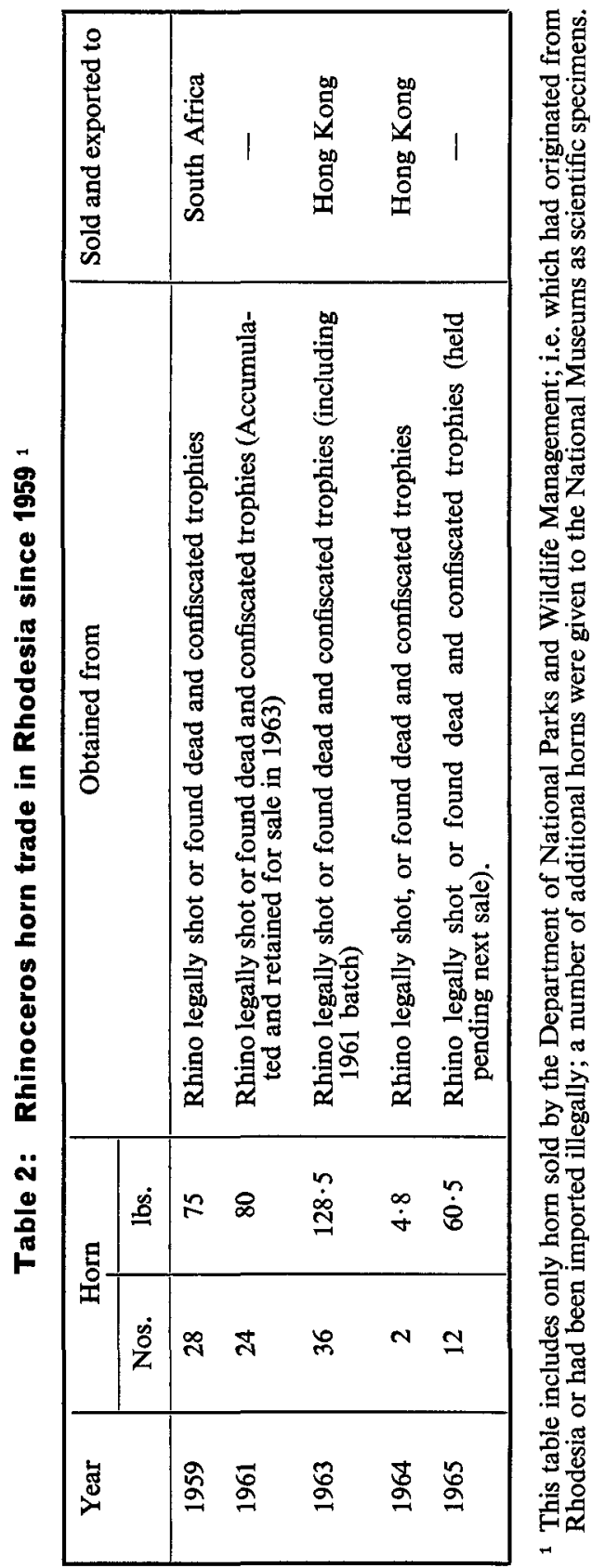


The Sabi River system in the eastern districts was also inhabited by black rhinoceros in the early days and Selous (1908) records seeing this species in 1883 on the Murihari River, some 10 miles west of the Sabi. However, rhinoceros must have become rare in the Sabi Valley much earlier than in northern Mashonaland since Townley (1965 pers. comm.), a naturalist living there since the early twenties, cannot recall having ever seen signs of rhinoceros on the west bank. Further away from the valley they may have existed; Whittal of Humani Ranch remembers having heard of rhinoceros near the Mtsai Native Reserve on the upper Turgwe River around 1940. It seems, therefore, that the well-known rhinoceros population in the Chipangayi hills on the eastern side of the valley (see below) was probably already isolated before the First World War. Around 1930 they seem to have still roamed between Taganda River, the vicinity of Chipinga Township, and Hippo Mine in the south, but to have been driven since then into the protection of an ever decreasing area of the rugged eastern Sabi escarpment. No evidence was found for an original southeastward connection of this population with the rhinoceros in the Rio Save area across the Mozambique border.

As mentioned above, historical hunting records from the Midlands and the southern Lowveld are scarce. Although rhinoceros in the ShashiSemokwe-Shashani area between the present Plumtree and the old Fort Tuli, favourite hunting grounds of the early travellers to Bulawayo, were shot out quite early, the last rhinoceros known to have been killed on the Limpopo, near Rhodes Drift, dates as late as about 1935 (Henderson 1965 pers. comm.). Further towards the Mozambique border, Townley (1965 pers. comm.) in 1937 obtained evidence of a live rhinoceros south of the Lundi River near Fishan. Another reliable hunter, however, Capell (1901-42 archived diary) did not record any signs of rhinoceros when he was searching for nyala down the Nuanetsi River in 1918.

In the Gwaai-Shangani River system, north-east of the BulawayoVictoria Falls railway line, the black rhinoceros survived the slaughter of the white rhinoceros and was still plentiful when the systematic tsetse control hunting campaigns started in that area in the 1920s. Schulz (1964 pers. comm.) recalls capturing rhinoceros for zoological gardens on the Dett Vlei after the first World War, and according to Davison (1964 pers. comm.) they occurred until 1925 in the northern parts of the present Wankie National Park. After 1927, when the area was first declared a game reserve, the rhinoceros disappeared, and survived only in small numbers in the adjacent area of Botswana and further north in the Zambesi valley.

\section{Present Distribution}

The white rhinoceros was first re-introduced from Natal into Rhodesia in 1962 (see below) and liberated in two localities, the Matopos National Park and the Kyle Dam Game Reserve. Following further introductions the species is now established and these areas can be regarded as being inhabited by the white rhinoceros.

The present distribution of the black rhinoceros was investigated in 1961-62, along with other large game species, by Child and Savory (1964) 
by means of a questionnaire survey. In contrast to its almost complete disappearance from the northern Zambesi bank (Ansell 1960), it was still present over large areas of the southern tributary system, roughly between Sebungwe and Hunyani Rivers. A few animals might also still survive between the Matetsi, Deka, and Mbilizi, since a fully grown raiding bull was shot on the Deka River in 1963, and rhino droppings were seen by Child (1967 pers. comm.) near the Sebungwe-Zambesi confluence in 1959 60 . At the same time a rhino was poached about twenty miles south of Binga. The recent re-introduction of tsetse control game operations along the Zambesi tsetse fly belt has made it possible to determine the present limit of the Zambesi rhinoceros range more accurately and this is shown on the map. Apart from this main area, isolated pockets of rhinoceros have become known from the Gwelo, Mt. Darwin and Mtoko Districts. In the Chipinga District a relict rhinoceros population has survived in the Chipangayi hills between the Chipangayi and Naodsa River systems, surrounded by relatively dense settlement. Individual animals are still seen occasionally down in the Sabi Valley near the junction of the Chipangayi River.

Restocking of the Wankie National Park with rhinoceros from the Zambesi valley began in 1962 and is described below.

\section{Abundance and Numbers of Black Rhinoceros}

In some areas of the southern bank of the Central Zambesi valley the black rhinoceros is quite abundant; in fact the species may be more numerous there now than it used to be, judging from reports of former Government officials patrolling the valley in 1910/12. Together with the Luangwa Valley in Zambia this area may be regarded as the last stronghold of the black rhinoceros in central and southern Africa.

In connection with the rescue of all rhinoceros marooned on islands during the formation of Lake Kariba from 1959 to 1963, Roth and Child (1964) investigated the density and structure of the rhino population in the flooded valley area. The overall mean density in the studied area between Sanyati and Mwenda Rivers was one rhino per 4-5-5·3 square miles. There was a marked dependence of the local rhino abundance on the degree of human settlement. The greatest local density was found to be $3 \cdot 4-4 \cdot 1$ square miles/rhino in a section of the Zambesi Valley west of the Sengwa River, which was virtually unsettled and known to have abundant rhinoceros. Considering that the population studied was relatively undisturbed - this part of the flooded Zambesi valley was only sparsely settled by an agriculturist tribe - these figures are regarded as applicable in general to other parts of the valley. In some restricted, remote and completely unsettled areas the general density of rhino is probably greater and may average as much as one rhino per 2-3 square miles. This figure comes close to overall rhinoceros densities in game reserves in other parts of Africa, in which related investigations were undertaken. It does not preclude the possibility that local overpopulations of several rhino per square mile, as reported from Hluhluwe Game Reserve (Deane 1964 pers. comm.) may exist locally. Based on these figures and considering that conditions in the area concerned are fairly uniform, the rhino population in the 
RHODESIA

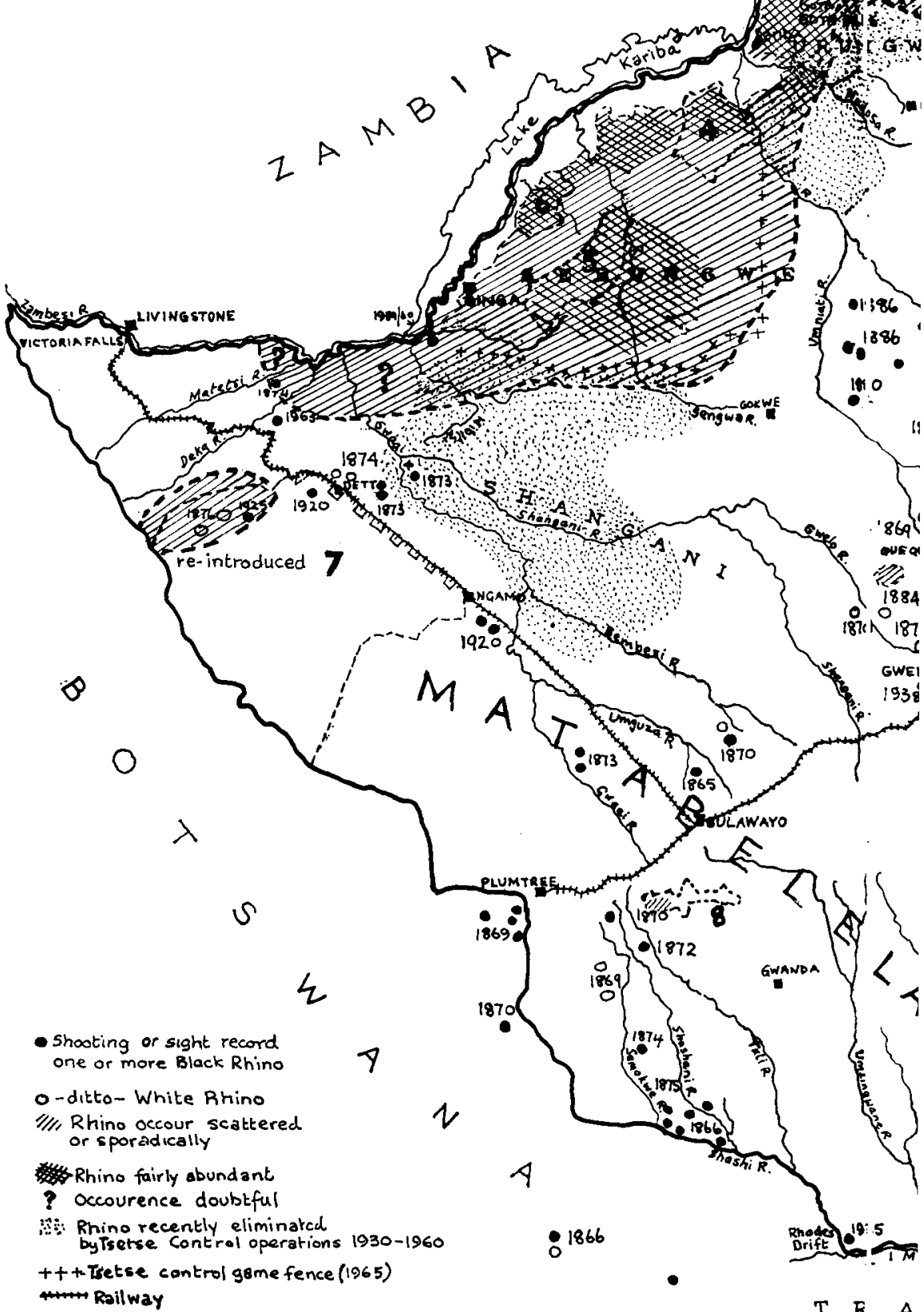

Key: 1. Chewore Wilderness Area 2. Urungwe Controlled Hunting Areas 3. Mana F Area 6. Chete Wilderness Area 7. Wankie National Park (black rhino re-introduced)

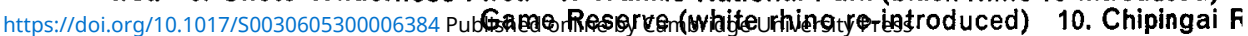



Zambesi drainage between Kariba Gorge and the Mozambique border may be very roughly estimated at 590-750 animals, of which it is hoped about 500-600 are living on national land. For the rest of the main distribution area it is very difficult to arrive at any definite numbers because settlement and habitat conditions vary widely. Applying density indices varying between 4-10 square miles/rhino for the different regions, a total of about 400-650 rhinoceros could optimistically be expected to live south of Lake Kariba, of which only about 200-240 may be inhabiting national land.

The rhinoceros of the Mazoe River in Mt. Darwin District have not yet been surveyed, but the District Commissioner has reported numbers to be about 22 animals. The relict population in the Sabi Valley occupies an area of about 20-30 square miles and is estimated to be about 8-12 head only. These rhino have survived despite being separated from any others for at least forty years, and the population seems to have maintained its numbers over the last two decades despite their extreme exposure to illegal hunting (see Table 1).

From these abundance figures, and allowing for another 10-20 animals in the other isolated localities, it may be concluded that the number of black rhinoceros given for Southern Rhodesia in the Red Data Book of IUCN, namely 1,500 , is probably on the high side. The total of 1,000 1,400 rhinoceros calculated in this study is, of course, only a very rough estimate, but since it is based on some detailed knowledge of the species distribution and local density, it is more accurate than any numbers given previously. Considering that the species range will continue to diminish rapidly it is also certain that whatever the precise number may be, the total number of rhino is decreasing.

\section{Conservation of the Black Rhinoceros}

The conservation prospects for the black rhinoceros in Rhodesia are largely determined by their occurrence either on tribal trust land or on national land. Whereas the latter is set aside for forestry, recreational and conservation purposes, tribal trust land is subjected to rapidly growing settlement pressure from the increasing African population. Rhinoceros do not withstand human disturbance and environmental changes for prolonged periods, and this settlement, which has steadily expanded over the last decades into the lower and tsetse-fly-infested areas, encroaching on the rhinoceros habitat all along the fringes of their main area, has reduced the rhinoceros range to less than ten per cent of its original size.

The settlement process was accompanied by extensive tsetse control operations which have in fact taken a heavy toll of rhinoceros in addition to the disturbance and habitat change. The long-lasting effect of tsetse control hunting on rhino populations has become quite evident from Roth and Child's study in the Lake Kariba basin. In the flooded areas east of the Sanyati River, which held an abundant rhino population prior to tsetse control operations in this area (Lovemore 1963, pers. comm.), no rhinoceros at all were found, as compared with an average of one rhino per 5-6 square miles on the western side of the river. The lower Sanyati was probably a natural barrier to rhinoceros and formed the boundary of 
tsetse control hunting activities between 1944 and 1950. The areas in which rhino were eliminated during tsetse control operations are shown on the map, and the total number of destroyed rhinos shown in Table 1 must certainly be regarded as a minimum figure. Since 1960 the rhinoceros has been excluded from the list of species to be shot in tsetse control operations; nevertheless these operations still aim at the removal of rhinoceros from the areas concerned. Experience has shown that rhinos resident in tsetse hunting areas usually leave after one or two years of disturbance, but probably only some of these have settled in successfully further down in the Zambesi valley. The present game fence along the Zambesi tsetse fly belt may be regarded, therefore, as the limitation of rhinoceros on tribal land; the map shows that a relatively limited amount of land is left between the game fence and the reserved areas in the Zambesi drainage, on which, however, a considerable number of rhinoceros are still resident. Tsetse operations are unlikely to affect these in the near future, but their presence will conflict sooner or later with the expanding human settlement. The only way to save rhinoceros in tribal areas which are being developed for settlement is by translocation to game reserves.

To save the isolated rhinoceros population on the Mazoe River efforts are being made to incorporate this area into an adjacent island of unreserved national land and to have this declared a game reserve. In a similar move in 1959 the Wildlife Conservation Department tried to establish the Chipangayi area as a game reserve for the relict Sabi rhinoceros population, but failed due to the opposition of the local farming community.

Fortunately the majority of the remaining black rhinoceros in Rhodesia occur on national land. Altogether, approximately 4,670 square miles of the Zambesi drainage area have been declared either game reserve, wilderness or controlled hunting area during recent years.

Chewore Wilderness Area (1,093 square miles) is completely closed to any traffic and may only be toured on foot. It holds the densest rhino population in Rhodesia, which may be $260-300$.

Urungwe Controlled Hunting Areas (1,650 square miles) comprise most of the central Zambesi Valley between Lake Kariba and the Mozambique border. Except for the Mana Pools Game Reserve (475 square miles), which is surrounded by the hunting area, Urungwe was opened up to licensed sport hunting in 1961, mainly in order to reduce the pressure of game overpopulation. Rhinoceros are distributed more or less over the whole area and their total number is estimated to be in the region of 270-320.

Matusadona Game Reserve (539 square miles), an inaccessible and mountainous area adjacent to Lake Kariba, was created mainly to give shelter to several thousands of game animals rescued from islands during the formation of Lake Kariba between 1960 and 1963 including 12 rhinoceros. The resident rhino population has not been surveyed, but for the purpose of this record is estimated at 50-60 animals.

Chizarira Wilderness Area (561 square miles) includes the Chizarira mountain range, some 20 miles south-east of the Lake Kariba shore. It is completely undeveloped and not open to traffic. Being located in the 
centre of the Zambesi tsetse fly belt it holds a fair rhino population estimated at 90-110 head. Due to the resettlement, in the vicinity of the Chizarira mountains, of the Tonga people who had to be evacuated from the Zambesi Valley, considerable poaching pressure has developed. However, it is intended to raise the status of the area to that of a national park which will make effective policing possible. This very attractive reserve will become a most important refuge for the Zambesi rhinoceros. Chete Wilderness Area (353 square miles), also beside Lake Kariba, is to remain completely undeveloped; entry is by boat from the lake. A considerable part of this reserve has been allocated to the University College of Rhodesia for research purposes, and rhinoceros are abundant.

All these reserves offer extensive habitat to the black rhinoceros as they are almost completely without any settlement. Conservation of this species there is, therefore, dependent on effective poaching control and appropriate management. Since the early rhinoceros slaughter described above, commercialised large-scale poaching and the rhino horn trade have probably not been as great a threat to the black rhino in Rhodesia as in East Africa, and rhino poaching, except for some losses through illegal tribal hunting and snaring, is generally well controlled. But the build-up of local overpopulation as a result of complete protection is now probably an equally serious problem. Rhinoceros are distributed rather unevenly, and in some areas more rhinoceros have been found to live closely together than the range could carry, resulting in habitat destruction, ill-health and increase of parasite infestation; high mortality of young animals and die-offs were observed, without any dispersal of the population into adjacent less densely occupied areas. If the rhino population as a whole is to be conserved, these local concentrations must be reduced. However, this does not imply the necessity of hunting. Drug immobilisation techniques are so well advanced that surplus rhinoceros may very well be removed to other vacant areas. The overall number of black rhinoceros in Africa has reached such a low level that the cost and effort of saving individual animals are well warranted. In 1965 licensed sport hunting of this species was, therefore, suspended altogether in Rhodesia in favour of capture operations.

\section{Relocation and Redistribution of Rhinoceros}

The first relocation of white rhinoceros from Natal into Rhodesia was described in detail by Davison and Condy (1963). The necessary funds of $£ 5,000$ were provided by the Federal and Southern Rhodesia Governments in conjunction with public subscriptions following a national appeal by the Natural Resources Board. In order to reduce the risk of introduction into a habitat not known to be perfectly suitable for the species, one juvenile male with three juvenile females were liberated in the Matopos National Park and another two juvenile couples in the Kyle Dam Game Reserve. In these fenced and newly established reserves it was possible to keep the introduced white rhinoceros under close observation. Both groups settled in very well when released after several weeks in their introduction pens. Although one female was lost in October 1964, due to drowning in a mud hole when the water level of Lake Kariba was particularly low, the Kyle 
Dam Game Reserve was considered to offer better conditions than Matopos for the establishment of a breeding nucleus of white rhinoceros. The greatest part of its 10,000 acres is open grassland, interspersed with Acacia, Albizzia, Pilostigma, and Peltopharum. Apart from the dominating Hyperrhenia and Loudetia species, there is a diversity of other grasses of the Cymbopogon, Cynodon, Urochloea, Heteropogon, Pogonarthra, Aristida, Eragrostis, Panicum and Themeda types available in the reserve. In 1964 the Natal Parks, Game and Fish Preservation Board kindly offered, free of charge, 12 white rhinoceros for the stocking of Kyle Dam Game Reserve, of which the first four had been successfully translocated by the end of 1965 through the contracting services of Messrs. Chr. Schulz of Okahandja, South West Africa. In order to relieve the rapidly growing pressure of rhinoceros overpopulation in the Natal game reserves, the Natal Parks and the Rhodesia Department of Wildlife Management agreed to shift altogether up to a hundred white rhinoceros. To reduce costs and to speed the translocation it was decided to take the risk of direct non-stop transport from the capture site to the areas of liberation, i.e. to move the animals a distance of 800 miles without prior taming down under drug anaesthesia. Player (1967) has reported that by this new method another nine rhinoceros were successfully translocated to Kyle Dam Game Reserve by October 1966. The operation continues, and when Kyle Dam Game Reserve is stocked to carrying capacity it is hoped that Wankie National Park will be re-populated with white rhinoceros.

The drug immobilisation technique has also made the redistribution of the black rhinoceros possible. Individual animals can now be removed from areas of agricultural or industrial development and transferred to the nearby safety of game reserves and national parks, and local rhino concentrations may be reduced. The technique was first applied to black rhinoceros in Rhodesia during the flooding of the Zambesi Valley and the gradual formation of Lake Kariba. Between 1960 and 1963 a total of 39 black rhinoceros marooned on islands were captured and transferred to the mainland, where they were mostly released into the Matusadona Game Reserve. From 1962 to the end of Operation Noah in 1963, efforts were made to use as many rescued rhino as possible to restock Wankie National Park. Captured rhino were tamed down in local holding pens, crated and sometimes rafted over 70 miles to Kariba harbour from where they were then transported via Livingstone over 450 miles of road to an introduction camp near Mandova Dam in the northern part of the Wankie Game Reserve. Altogether 13 rhino ( 7 male and 6 female) were translocated from Lake Kariba to Wankie; nine were fully grown and mature weighing with their crates up to $4,000 \mathrm{lb}$ each. In spite of all care, two animals succumbed to the stress and died during transport or shortly after arrival in Wankie. The others, after a period of observation, were released from the paddock into the park. During the first year four or five settled down in the northern part of the reserve, and two moved into the adjacent Wankie Controlled Hunting Area. Only two seem to have migrated, probably into Botswana; two killed each other in a fight.

Restocking operations were continued in 1964 and 1965 from a tribal 
area in Sebungwe District which was to be opened up for more intensive settlement. The Government authorities responsible for African settlement requested the Department of National Parks and Wildlife Management well in advance to prepare and budget for the evacuation of rhinoceros from this area, themselves providing considerable funds as part of the settlement costs - a good example of the integration of wildlife conservation into the planning of agricultural development. Co-operation between the two Departments resulted in the capture of 38 rhinoceros in the area, of which 30 (16 males and 14 females) were successfully translocated into Wankie National Park, increasing the re-introduced rhinoceros stock considerably. Not all of them settled in, and some definitely wandered off to Botswana, but the operation re-established a rhino nucleus sufficient for gradual natural repopulation of the area. Two immature calves, which would have been endangered by lion if released without their mothers, were sold to Zoological Gardens and this contributed to the expenses.

\section{Legal Status and Horn Trade}

Protection and control of wildlife in Rhodesia is provided for under the Wildlife Conservation Act, passed by Parliament in 1960. Unlike the white rhinoceros, the black is not scheduled as Royal Game (fully protected), but it is excluded from landholders' and general hunting licences, and may be hunted only on special supplementary licence. Between 1961 and 1964 a total of 18 rhino were permitted to be shot in the Zambesi controlled hunting areas only. In 1964, in order to reduce the demand for rhino licences, the fees were increased to $£ 100$ and $£ 150$ for residents and non-residents respectively; in 1965 the rhinoceros was removed altogether from the list of species allowed for sport hunting. It is, however lawful to kill a rhinoceros in self defence, and for a landowner or occupier of land to destroy on his land rhinoceros causing damage to any livestock, crop, water installation or fences. The onus of proving that the destroyed animal was in fact killed in self defence or was causing damage rests with the person concerned, who is obliged to report to the police as soon as possible and to surrender the trophy. Because rhinoceros no longer inhabit European-owned land only two rhinos have been killed so far under this legal provision. The sale, import and export of rhinoceros horn in Rhodesia are also governed by the same Act, which provides for the registration with the Wildlife Department of any rhino horn, whether imported or obtained inside the country. Certificates of ownership, showing the registration numbers punched on to the horn, are issued to legal owners of rhino horn. When horns are sold these certificates are endorsed and transferred with the goods to the new owner. Import and export licences are issued only to legal owners. Furthermore, persons who intend to trade in ivory and rhino horn are requested to purchase a trophy dealer's licence and to submit periodical returns on the numbers of trophies dealt with, their origin and registration numbers.

In the past most rhino horn from Rhodesia has gone to the Far East or to Zanzibar. In 1963, for example, local traders imported, mainly from Zambia and Angola, 113 horns weighing $407.5 \mathrm{lb}$. of which $80 \%$ was shipped to Zanzibar, $1 \%$ to the Middle East and $9 \%$ sold locally. Rhino- 
ceros horns confiscated or obtained by wildlife officers are collected and sold as shown in Table 2. In 1963 one pound of horn fetched $£ 210$ s. $6 \mathrm{~d}$.

\section{REFEREN CES}

ANSELL, W. F. H. 1960, Mammals of Northern Rhodesia. Gov. Printer, Lusaka; $155 \mathrm{pp}$.

BIGALKE, R., 1963, The extermination of the square-lipped or white rhinoceros (Ceratotherium simum (Burch.)) in Transvaal and its reintroduction. A historical and critical review. Fauna and Flora, Pretoria; 14; p. 5-14.

BULPIN, T. R., 1962, Ivory Trail.

CHILD, G. and SAVORY, C. R., 1964, Distribution of large mammal species in Southern Rhodesia. Arnoldia 1 No. 14.

CORYNDON, R. T., 1894, Occurrence of the White or Burchell's rhinoceros in Mashonaland. Proc. Zool. Soc. London, 1894; p. 329-334.

DAVISON, E., CONDY, J. B., 1963, The importation of eight square-lipped rhinoceros (Ceratotherium simum) to Southern Rhodesia. In: Operation White Rhino; Natural Resources Board, Salisbury, S. Rhodesia; 1963, p. 4-9.

HARPER, F., 1945, The extinct and vanishing mammals of the old world. New York, 1945.

HELLER, E., 1913, The White Rhinoceros. Smithsonian Misc. Coll. Washington, 61 No. $1 ; 77 \mathrm{pp}$.

LANG, H., 1923, Recent and historical notes on the square-lipped rhinoceros (Ceratotherium simum). J. Mammal. 4; p. 155-163.

PLAYER, I. C., FEELY, J. M., 1960, A preliminary report on the squarelipped rhinoceros. The Lammergeyer (Natal Parks, Game and Fish Pres. Board, Pietermaritzburg) 1; p. 3-24.

PLAYER, I., 1967, Translocation of white rhinoceros in South Africa, Oryx, ix, $137-150$.

ROTH, H. H., CHILD, G., 1967, Distribution and population structure of black rhinoceros (Diceros bicornis L.) in the Lake Kariba basin. Zschr. Säugetierkd. (in press).

SELOUS, F. C., 1881, A hunter's wanderings in Africa; 1881; London; p. 81-92.

SELOUS, F. C., 1881, On the South African rhinoceroses. Proc. Zool. Soc. London, $1881 ;$ p. 725-734.

SELOUS, F. C., 1908, African nature notes and reminiscences. London, 1908; p. 178-204.

ZUKOWSKY, L., 1964, Die Systematik der Gattung Diceros Gray, 1821, D. Zool. Gart. (NF) 30; p. 1-178.

\section{ACKNOWLEDGMENTS}

Dr Erika Roth has compiled most of the historical data and without her assistance this study would not have been possible. Mr R. H. N. Smithers, Director of National Museums, has kindly encouraged this report and his advice is gratefully acknowledged. Staff of the Department of National Parks and Wildlife Management and of the Tsetse Control Branch of the Department of Veterinary Services, as well as the numerous older residents who have contributed so readily to this survey are thanked. The Director of National Parks and Wildlife Management has very kindly permitted me to utilise and to publish departmental records for the purpose of this report.

The rock painting from Matopo Hills, Rhodesia, is reproduced from Prehistoric Rock Art of the Federation of Rhodesia and Nyasaland, edited by R. Summers. National Publications Trust Salisbury 1959.

The map showing the historical distribution of black and white rhinoceros in Southern Rhodesia has been compiled according to Harris (1838), Livingstone (1857, 1865 and cit. Waller 1874), Leask (cit. Wallis 1954), Drummond (1876), Finaughty (cit. Finaughty 1957), Baines (cit. Wallis 1946), Selous 1881a, 1881b, 1809), Oates (1881), Wood (1893), Bryden (1893), Nicolls and Eglington (1892), Coryndon (1894), Chubb (1909), Capell (1901-42), Kemp (pers. comm.), Davison (pers. comm.), Scott (pers. comm.), Henderson (pers. comm.), Child (pers. comm.). 